\title{
Regulering av jernbalansen
}

\begin{abstract}
Sammendrag
Bakgrunn. Tidligere har regulering av jernabsorpsjonen blitt omtalt som «en gåte», men senere års forskning har bidratt med mye interessant forskning. Hensikten med artikkelen er å gi en oppdatert oversikt over normal regulering av jernbalansen og regulering ved patologisk jernoverskudd.
\end{abstract}

Materiale og metode. Artikkelens grunnlag er ikke-systematiske søk i databasen PubMed med et skjønnsmessig utvalg av artikler basert på forfatternes kompetanse innen feltet.

Resultater. Peptidet hepcidin binder seg til eksportproteinet ferroportin på enterocytt-, makrofag- og hepatocyttmembranen. Ferroportinhepcidinkomplekset internaliseres og degraderes. Resultatet er nedsatt eksport av jern fra enterocytter og makrofager til sirkulasjonen, som fører til nedsatt plasma-jernnivå. Hepcidinproduksjonen oppreguleres ved jernoverskudd og nedreguleres ved jernmangel. Hemokromatoseproteinet (HFE), transferrinreseptor 2 (TfR2), hemojuvelin (HJV) og beinmorfogeneseproteinet (BMP) er nødvendige regulatorer for aktivering av hepcidinsyntesen. Mangel på eller mutasjoner i genene for disse proteinene, f.eks. HFE-mutasjonen $\mathrm{C} 282 \mathrm{Y}$ ved primær hemokromatose, nedsetter hepcidinsyntesen. Jernregulerende proteiner (IRP) kan binde seg til jernfølsomme sekvenser (IRE) i ferritin-mRNA og transferrinreseptormRNA og regulere proteinsyntesen.

Fortolkning. Regulering av opptak, forbruk, utskilling og lagring av jern foregår på gennivå. Hepcidin anses for å være hovedregulatoren av jernbalansen. Intracellulær jernbalanse opprettholdes ved hjelp av jernregulerende proteiner. Ved forhøyet jernnivå øker syntesen av ferritin, mens TfR1-syntesen reduseres. Ved lavt jernnivå er forholdet omvendt.

\section{Berit Borch-lohnsen}

berit.borch-iohnsen@medisin.uio.no

Avdeling for ernæringsvitenskap

Institutt for medisinske basalfag

Universitet i Oslo

Postboks 1046 Blindern

0377 Oslo

\section{Tor-Arne Hagve}

Avdeling for medisinsk biokjemi

Rikshospitalet

og

Fakultetsdivisjon Akershus, universitetssykehus Lørenskog

\section{Anton Hauge}

Avdeling for fysiologi

Institutt for medisinske basalfag

Universitetet i Oslo

\section{Ketil Thorstensen}

Avdeling for medisinsk biokjemi

St. Olavs hospital

Jern er en essensiell komponent i kroppens forskjellige prosesser, og transport av oksygen ved hjelp av hemoglobin er den kvantitativt viktigste. Total jernmengde i en frisk, voksen person (2-6 g) holder seg bemerkelsesverdig konstant. Dette skyldes tre forhold: at kroppen konserverer jernet effektivt, dvs. at normale jerntap er små; at jernopptaket balanserer tapet; og at jern absorberes mer effektivt ved jernmangel. Mekanismen for kontroll av jernabsorpsjonen har hittil for en stor del vært ukjent, men senere års forskning har gitt oss mye interessant informasjon.

Målet med denne artikkelen er å gi en oppdatert oversikt over regulering av jernstoffskiftet. For å belyse detaljer i mekanismene for regulering brukes patologisk jernoverskudd.

\section{Materiale og metode}

Grunnlaget for artikkelen er et ikke-systematisk søk i databasen PubMed med skjønnsmessig utvalg av artikler, basert på forfatternes kompetanse og erfaring innen feltet. Forfatterne har deltatt i forskning innen jernstoffskiftet.

\section{Normalt jernstoffskifte}

Jern er nødvendig for alle former for liv, fra bakterier til mennesker, men kan også gi skade. Det skyldes at jern har evnen til å motta og avgi elektroner. Når jern forekommer i cellenes cytosol som $\mathrm{Fe}^{2+} \mathrm{i}$ lavmolekylære forbindelser (sitrat, pyrofosfat, aminosyrer; labil jernpool (LIP)), kan det katalysere danningen av reaktive oksygenradikaler, som så kan ødelegge ulike cellestrukturer og føre til celledød. Dette motvirkes ved at jern bindes til hemproteiner, som hemoglobin til oksygentransport, myoglobin til oksygenlagring og bl.a. cytokromer til oksidativ fosforylering. De intracellulære lagringsproteinene for jern, ferritin og hemosiderin, og transferrin som transporterer jern i blod, er ikke-hemproteiner.

En frisk, voksen person har 2-6 g jern i kroppen, fordelt på hemoglobin (70\%), myoglobin og enzymer (10\%), plasma-jern $(0,1 \%)$ og ferritin/hemosiderin $(20 \%)$.

Jern resirkuleres effektivt. Plasma-transferrin leverer ca. $25 \mathrm{mg}$ jern per dag (fig 1) til beinmargen til syntese av hemoglobin i nye erytrocytter. Mesteparten av dette jernet stammer fra makrofager i det retikuloendoteliale system (RES) ved fortløpende nedbrytning av 120 dager gamle erytrocytter. Bare en meget liten del (ca. $1 \mathrm{mg}$ ) tapes per dag gjennom avføring, svette og urin (basale tap). Omkring 10-15\% av kostjernet absorberes fra tarmkanalen, og tap av jern balanseres ved en jerntilførsel i kosten på noe under $10 \mathrm{mg}$ per dag. Kvinner i fertil alder har i tillegg til dette et jerntap på grunn av menstruasjon og anbefales en tilførsel på $15 \mathrm{mg}$ jern daglig.

\section{Jernabsorpsjon fra kosten}

Jernabsorpsjonen foregår hovedsakelig i duodenum, men kan skje i hele tynntarmens lengde. Opptaket av jern fra et variert kosthold er avhengig av behovet for jern, kostens innhold av jern og dens sammensetning for øvrig. Små jernlagre eller økt produksjon av erytrocytter fremmer den prosentvise absorpsjonen av jern fra tarmen, mens store jernlagre, høye jerninntak og nedsatt erytropoese nedsetter absorpsjonen.

Kostjern. Jernet i kosten forekommer både som hemjern og som ikke-hemjern. Hemjernet er bundet til globin og finnes

\section{Hovedbudskap}

- Hepcidin styrer jerneksporten fra enterocytter, makrofager og hepatocytter til transferrin i plasma

- Hepcidinsyntesen nedreguleres ved jernmangel og oppreguleres ved jernoverskudd

- Ved primær hemokromatose nedsettes produksjonen av hepcidin pga. C282Ymutasjonen i HFE-genet 
hovedsakelig i kjøtt, blod, innmat, fjærfe og fisk. Omkring $40 \%$ av jerninnholdet i disse matvarene er hemjern. Opptaket av hemjern er effektivt (absorpsjonsgrad 15-35\%) fordi det ikke påvirkes av kostfaktorer.

Ikke-hemjernet forekommer som treverdige hydroksider bundet til organiske molekyler og finnes både $\mathrm{i}$ vegetabilske og animalske matvarer. Det ioniseres til $\mathrm{Fe}^{3+}$ ved hjelp av magesyren og må reduseres til toverdig før opptak. Komponenter i kosten kan virke stimulerende eller hemmende på jernopptaket. Askorbinsyre som virker både som kelator og reduktant, er en viktig fremmer av absorpsjonen. I tillegg er det påvist en faktor, «kjøttfaktoren» (antakelig et peptid), som frigjøres under fordøyelsen av kjøtt, fjærfe og fisk som også fremmer opptaket av ikke-hemjern. Polyfenoler, som garvesyre i te og kaffe, samt fytinsyre i kornprodukter hemmer opptaket. Absorpsjonsgraden av kostens ikke-hemjern er 2-20\%.

Absorpsjon. Det treverdige ikke-hemjernet (fig 2) reduseres av ferrireduktasen Dcytb (Duodenal cytokrom B) før opptak i tarmcellene (enterocyttene). Proteinet divalent metalliontransportør1 (DMT1) frakter deretter jernet over den luminale cellemembranen og inn i enterocyttene. Disse cellene kan enten lagre jernet som ferritin (og tape det igjen når cellene avstøtes på toppen av villi) eller transportere jernet gjennom cellen. Ved den basale cellemembranen transporteres jernet gjennom membranen ved hjelp av eksportproteinet ferroportin (Fpn) og reoksideres til $\mathrm{Fe}(\mathrm{III})$ av ferroksidasen, hefestin. Kroppen regulerer jernnivåene ved å regulere de forskjellige trinnene; f.eks. vil det ved jernmangelanemi produseres mer Dcytb, DMT1 og ferroportin i enterocyttene $(1-3)$.

Hem spaltes fra globinet i magesekken og tas opp fra tarmlumen ved hjelp av et spesifikt hembærerprotein 1 (HCP1). Hem brytes så ned av hemoksidase, og det jernet som frigjøres behandles deretter som absorbert ikke-hemjern i den labile jernpoolen (LIP). Påvisning av to bærerproteiner for hem antyder muligheten for at intakt hem kan passere gjennom enterocytten og eksporteres til plasma (4).

Jern eksportert fra enterocytter blir raskt bundet til plasmaproteinet transferrin som transporterer jern til alle celler i kroppen, særlig til beinmargens umodne forstadier til erytrocytter. Transferrin har to bindingssteder for treverdig jern, og normalt er ca. $30 \%$ av transferrinet mettet med jern.

\section{Overføring av jern fra enterocytter} og makrofager til sirkulasjon

Opprettholdelse av jernhomøostase forutsetter en koordinert kontroll av tre hovedstrømmer av jern til transferrin i plasma: fra absorpsjon av kostjern i duodenum, fra resirkulering av jern fra nedbrutte røde blodceller (RBC) i makrofager (kvantitativt viktigst) og fra jernutskilling fra lager i leverceller (5). Den sirku- lerende jernmengden, uttrykt ved transferrinmetning (TfS), er essensiell både for selve jernforsyningen til erytropoetiske organer og andre funksjonelle steder der jern forbrukes, og som sirkulerende signal til hepatocytten om produksjon av det hormonliknende peptidet hepcidin (6).

Som beskrevet ovenfor og som vist i figur 2 , er overføringen av jern fra tarm til blod avhengig av samspillet mellom en rekke celleassosierte og sirkulerende faktorer. Hepcidin spiller her en sentral rolle ved at det binder seg til ferroportin (Fpn) på cellemembranen til enterocytter, makrofager og hepatocytter. Ferroportin-hepcidin-komplekset internaliseres og degraderes, noe som resulterer $i$ at mindre ferroportin uttrykkes på cellemembranen. Eksport av jern fra enterocytter og makrofager til sirkulasjonen går dermed ned, og dette reflekteres i lavere transferrinmetning fordi mindre jern blir tilgjengelig for binding til transferrin. Hepatocyttens hepci-

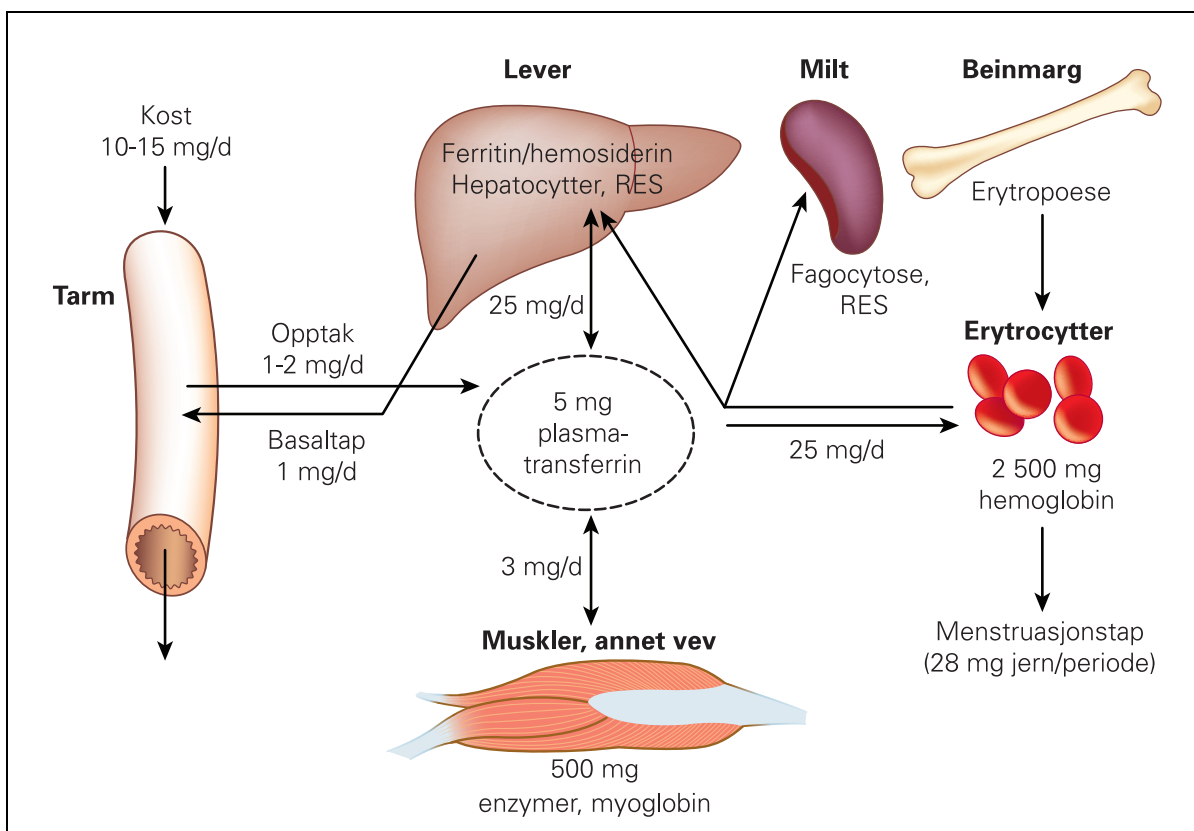

Figur 1 Oversikt over daglig jernomsetning. RES (det retikuloendoteliale system)

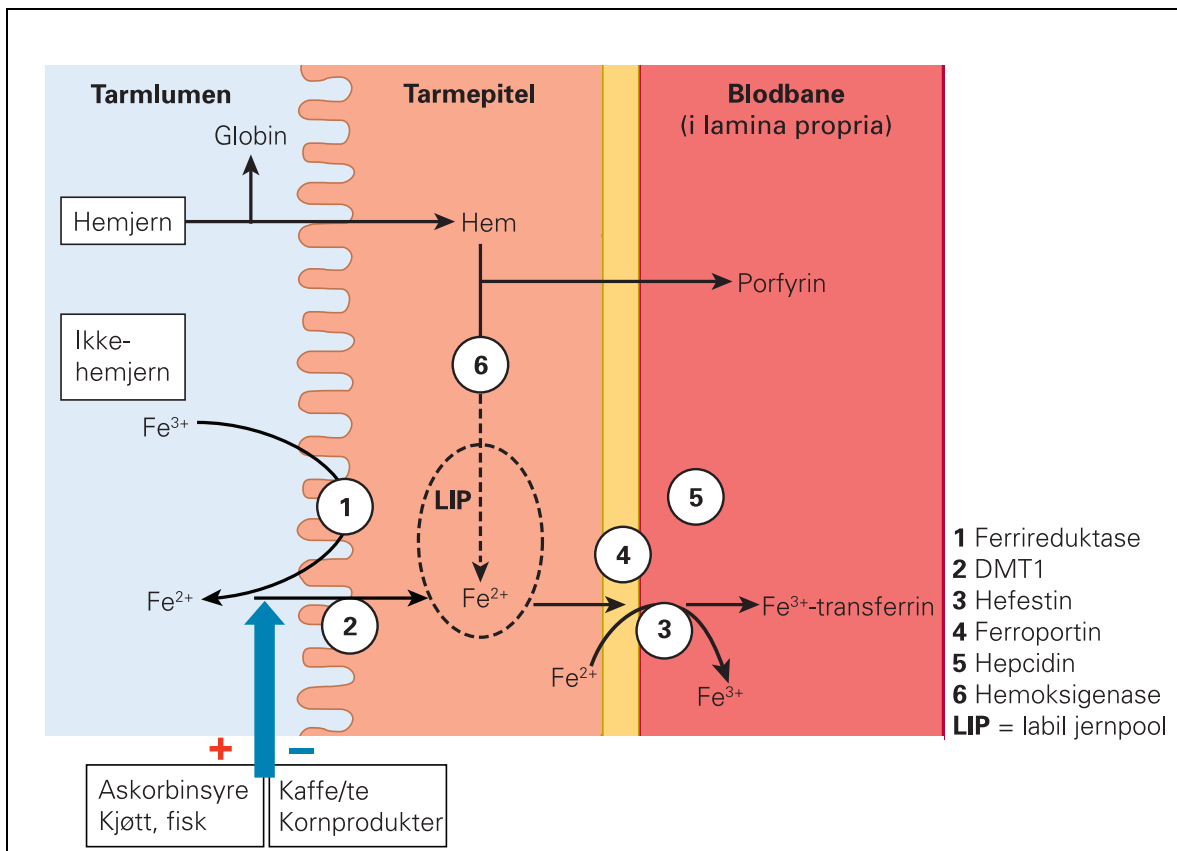

Figur 2 Normal absorpsjon av hemjern og ikke-hemjern i duodenale enterocytter og effekter av ligander i kosten. Ferrireduktase (duodenal cytokrom B; Dcytb); proteinet divalent metalliontransportør 1 (DMT1); et hembærerprotein 1 (HCP1); labil jernpool (LIP; lavmolekylære ferroforbindelser). Jern eksporteres via ferroportin, oksideres til ferrijern av hefestin (ceruloplasminliknende, Cu-holdig) og bindes til transferrin i plasma 


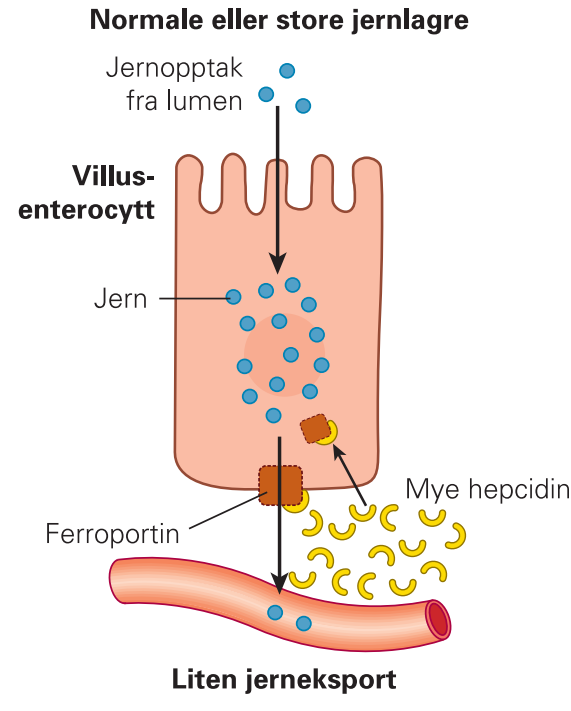

a

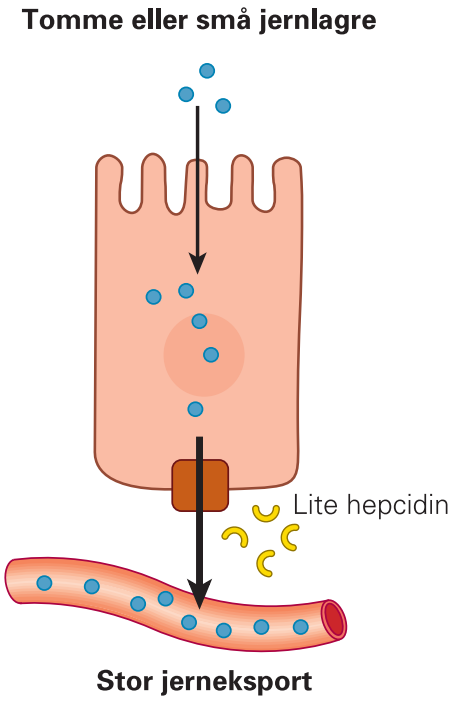

b

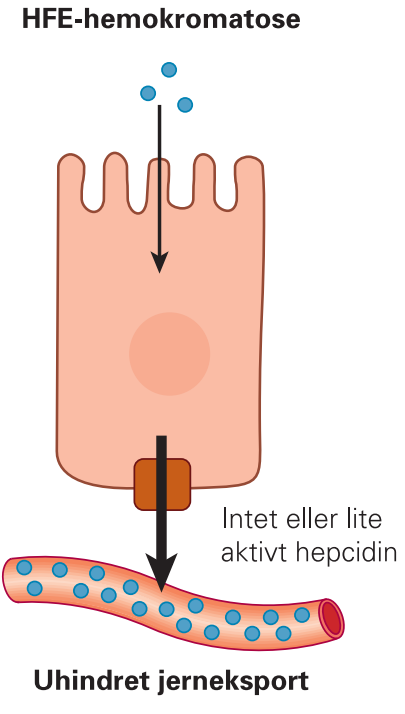

c

Figur 3 Jernopptak i enterocytter og eksport til plasma. al Normal absorpsjon; ved normal jernstatus produseres mye hepcidin som binder seg til ferroportin (Fpn). Komplekset internaliseres og degraderes og lite jern eksporteres til plasma. b) Normal absorpsjon; ved jernmangel produseres lite hepcidin og ferroportin «tillater» at mye jern eksporteres til plasma. c) Absorpsjon ved HFE-hemokromatose; lite eller inaktivt hepcidin produseres, og jerneksporten til plasma går uhindret via ferroportin

dinproduksjon responderer på transferrinmetningen (TfS) ved å oppreguleres ved jernoverskudd (TfS øker) og nedreguleres ved jernmangel (TfS faller) (fig $3 a, b)$.

For tiden antar man at fire nøkkelproteiner i lever - HFE, transferrinreseptor 2 (TfR2), hemojuvelin (HJV) og beinmorfogeneseprotein (BMP) - er nødvendige regulatorer for at syntesen av hepcidin skal aktiveres som svar på det sirkulerende jernsignalet, transferrinmetningen (7). Selv om mye fortsatt er uklart, ser man for seg et samspill omtrent som dette: Hemokromatosegenproduktet, HFE, kan binde $\beta_{2}$-mikroglobulin på utsiden av cellemembranen. Dette komplekset er assosiert med transferrinreseptor1 (TfR1) på

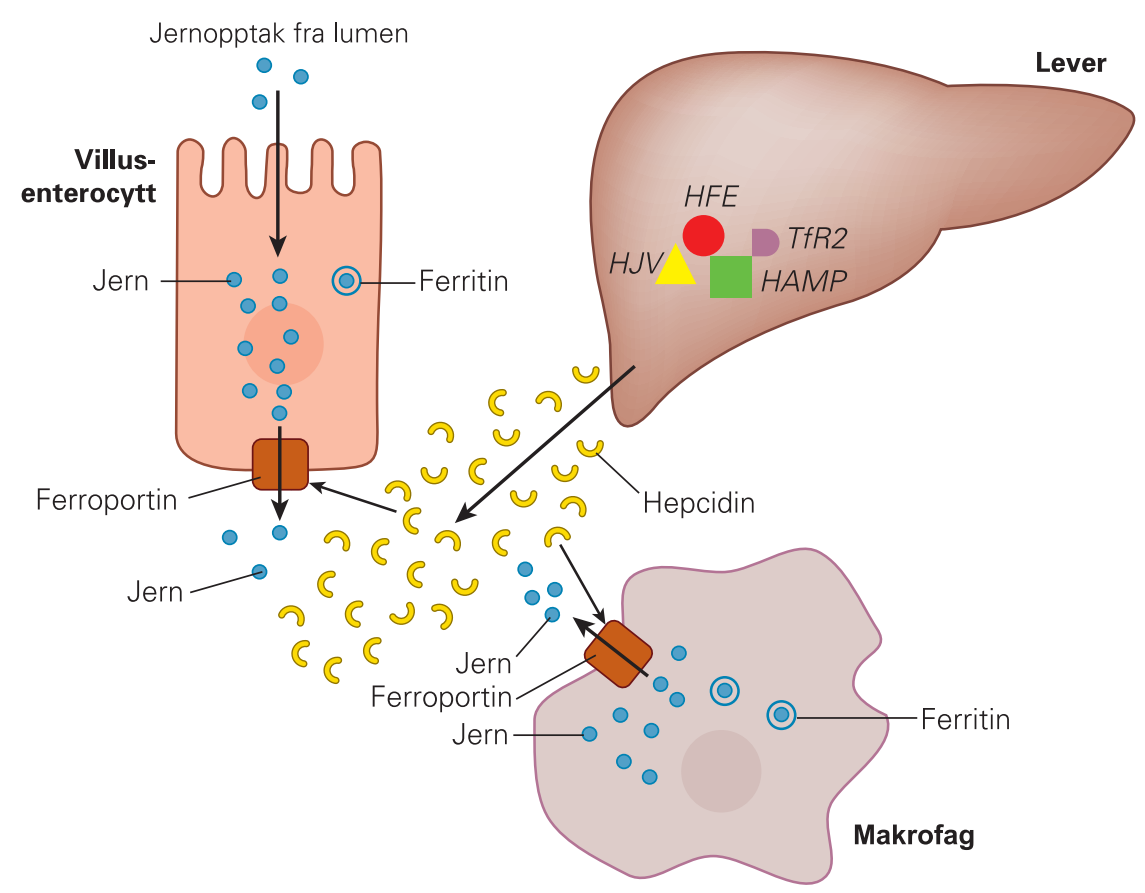

Figur 4 Normalt jernstoffskifte. De fire proteinene i lever, HFE, HJV (hemojuvelin), HAMP (hepcidin antimicrobial peptide) og TfR2 (transferrinreseptor 2), er normale. Hepcidin produseres i henhold til jernstatus og regulerer eksporten av jern fra enterocytter og makrofager

cellemembranen, noe som påvirker reseptorens affinitet for transferrin. TfR2 er homolog med TfR1 og kan også binde transferrin og frakte jern inn i celler. Mens TfR 1 er bredt uttrykt og har en nøkkelposisjon i cellers jernopptak, er TfR2 hovedsakelig uttrykt på hepatocytter, bloddannende celler og duodenale kryptceller, overlappende med celler som uttrykker HFE. Selv om TfR2 kan binde transferrin og frakte jern inn i celler, er det postulert at TfR2 er del av det regulerende system som oppfatter transferrinmetningen.

En aktuell hypotese er at HFE og TfR1 forekommer som et kompleks ved lave jernmengder i plasma (8). Diferri-Tf (transferrin med $2 \mathrm{Fe}^{3+}$ bundet) konkurrerer med HFE om binding til TfR1. Ved økende transferrinmetning (TfS) dissosierer HFE fra TfR1 og binder seg i stedet til TfR2. Dette komplekset overfører sin «viten» om TfS-status til cellen ved hjelp av en signalkaskade som involverer HJV og BMP, noe som i sin tur oppregulerer syntesen av hepcidin og nedsetter organismens jernopptak (7-9).

Hepcidin anses for tiden som hovedregulatoren ved å modulere omfang og hastighet av jerneksport fra enterocytter og makrofager (fig 4).

\section{Regulering av intracellulær} jernmetabolisme

Alle celler trenger jern og må få dette fra transferrin i sirkulasjonen. På celleoverflaten sitter transferrinreseptorer (TfR1), som binder transferrin. Ved endocytose internaliseres transferrin-TfR1-komplekset, og i endosomenes sure miljø frigjøres jern fra transferrin og transporteres over endosommembranen ved hjelp av divalent metallion- 
transportøren (DMT1). TfR1 med transferrin uten jern (apotransferrin) returneres til celleoverflaten der apotransferrin frigjøres til sirkulasjonen, mens TfR1 blir klar for ny binding av transferrin. Avhengig av cellens jernstatus og funksjon vil jernet enten lagres i ferritin, fraktes til mitokondriene for hemsyntese eller eksporteres ut av cellen. Hvilken retning jernet tar, er nøye regulert ved hjelp av spesielle strukturer på mRNA, såkalte jernfølsomme sekvenser (iron responsive elements, IRE), som regulerer translasjonen eller stabiliteten til mRNA. IRE finnes i nøkkelkomponenter i den intracellulære jernmetabolismen - i TfR1 og DMT1 (jernopptak), i ferritin (jernlagring), i $\delta$-aminolevulatsyntetase (ALAS; hemsyntese) og i ferroportin (Fpn, jerneksport). Sentralt i reguleringen står et jernregulerende protein (iron regulatory protein, IRP), som enten binder eller ikke binder seg til IRE, avhengig av cellens jerninnhold. Avhengig av om IRE er plassert i 5'- eller 3'- utranslaterte regioner (UTR) av mRNA, gir IRP-binding enten $ø k t$ eller nedsatt proteinsyntese (10-12). Dette gir cellen mulighet til å oppregulere syntesen av noen proteiner og nedregulere syntesen av andre som respons på samme stimulus, dvs. variasjoner i jernmengde.

Det klassiske eksemplet er balansen mellom opptak og lagring av jern gjennom regulering av syntesen av transferrinreseptor 1 (TfR1) og ferritin som vist i figur 5. Ved lavt jerninnhold binder IRP til IRE på TfR1mRNA og til ferritin-mRNA i hhv. 3'- og 5'UTR. Dette stabiliserer TfR1-mRNA, mens translasjonen av ferritin-mRNA hemmes. Resultatet blir økt syntese av transferrinreseptor og nedsatt syntese av ferritin. Med andre ord, når cellens jerninnhold er lavt, øker cellen sin kapasitet for jernopptak og reduserer sin lagringskapasitet. Når jerninnholdet øker, vil ikke IRP lenger binde til IRE. TfR1-mRNA destabiliseres og TfR1syntesen avtar (opptakskapasiteten senkes), mens blokkeringen av ferritinsyntesen oppheves (lagringskapasiteten økes).

\section{Endringer i jernstoffskiftet ved patologisk jernoverskudd}

Kronisk jernakkumulering i kroppen kan skyldes arvelig jernoverskudd (primær hemokromatose) eller ervervet jernoverskudd (sekundært jernoverskudd).

\section{Primær hemokromatose}

Det har vært vanlig å si at primær hemokromatose skyldes feil i reguleringen av jernopptak fra kosten; dvs. at jernabsorpsjonen er økt og resulterer i akkumulering av jern i forskjellige organer, eventuelt med organskade. Etter at hormonet hepcidin og dets virkninger ble påvist, er en mer moderne betraktning at jernoverskuddet skyldes en genetisk bestemt svikt i mekanismen som skal forhindre at unødvendig jern eksporteres fra enterocytten til den sirkulerende jernpoolen.

Mutasjoner i HFE-genet på kromosom 6 (ramme 1), hvorav C282Y er den viktigste, ble først beskrevet i 1996 (13). C282Y-mutasjonen medfører at cystein skiftes ut med tyrosin ved aminosyre 282. Derved brytes disulfidbroen mellom $\beta_{2}$-mikroglobulin og HFE-proteinet og HFEs funksjon ødelegges. Denne mutasjonen er vist å være årsaken til $90 \%$ av alle tilfeller av primær hemokromatose i befolkningsgrupper av nordvesteuropeisk avstamning. I disse populasjonene er frekvensen av homozygot C282Y av størrelsesorden $0,5-1,0 \%$, mens heterozygoti forekommer hos ca. $12-15 \%$. I den store screeningen for hemokromatose $\mathrm{i}$ helseundersøkelsen i Nord-Trøndelag (HUNT 2) i 1995-97 ble hyppigheten av C282Y-homozygoti beregnet til minst $0,68 \%$ (14).

Det er senere $(7,8)$ påvist flere mutasjoner i andre gener (TfR2, HJV), som også gir opphav til jernoverskudd ved å innvirke
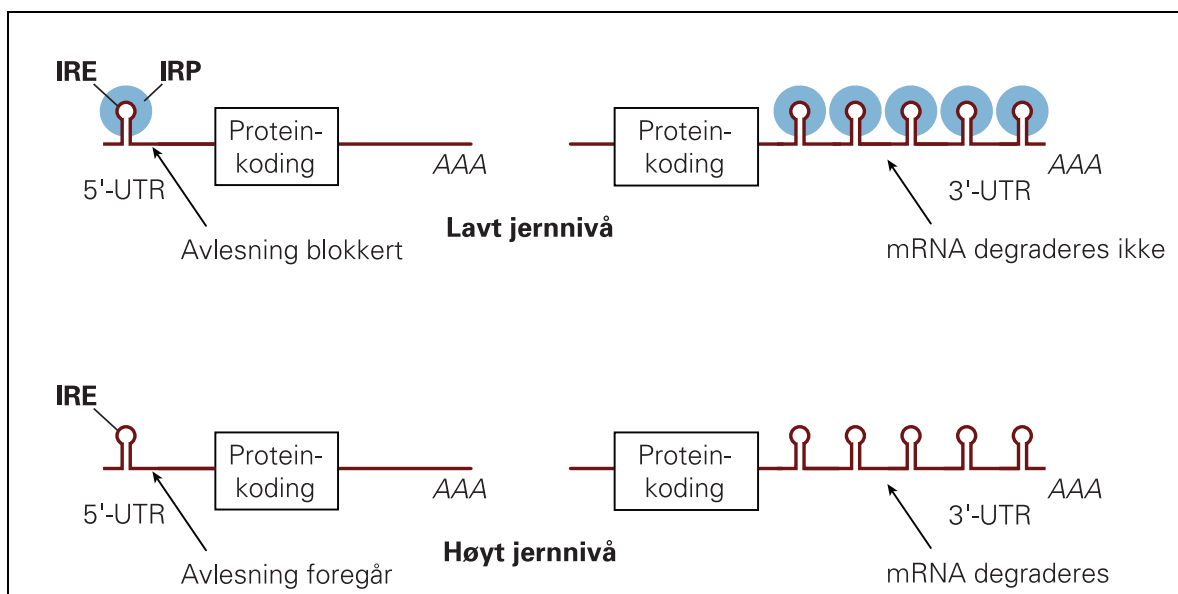

Ferritin-mRNA

Transferrinreseptor-mRNA

Figur 5 Regulering av transferrinreseptor- og ferritinsyntese via IRE og IRP. Ved lavt jerninnhold i cellen vil IRP binde til IRE i 3'-UTR på transferrinreseptor-mRNA og i 5'-UTR på ferritin-mRNA og føre til økt syntese av reseptoren og nedsatt ferritinsyntese. Ved høyt jerninnhold dissosierer IRP fra IRE og vil føre til nedsatt transferrinreseptorsyntese (redusert opptakskapasitet) og økt ferritinsyntese (økt lagringskapasitet) IRP (jernregulerende protein); IRE (jernfølsomme sekvenser); UTR (5'- eller 3'- utranslaterte regioner av $m R N A)$

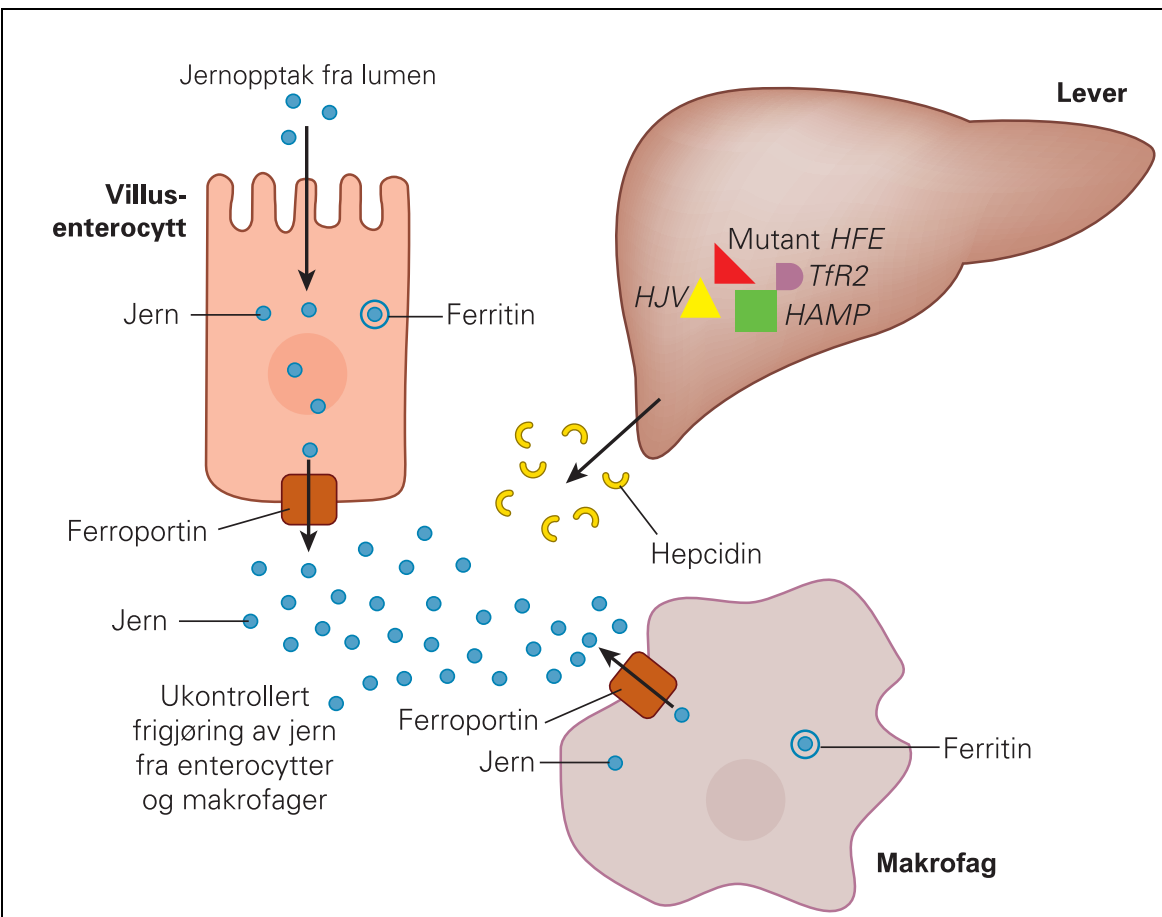

Figur 6 Jernstoffskiftet ved HFE-hemokromatose. Eksporten av jern fra enterocytter og makrofager til plasma er ukontrollert 


\section{Ramme 1}

\author{
Arvelig jernoverskudd \\ Knyttet til hepcidin \\ Autosomalt recessivt \\ Hemokromatose assosiert til mutasjo- \\ ner i HFE-genet på kromosom 6 \\ - C282Y homozygot (vanligste mutant) \\ - C282Y/H63D sammensatt lcompo- \\ und) heterozygot \\ Juvenilt arvelig jernoverskudd; muta- \\ sjon i hemojuvelin-genet på kromosom \\ 1 eller mutasjon i hepcidin antimicro- \\ bial peptide (HAMP) på kromosom 19 \\ - 2A: mutasjon i HJV \\ - 2B: mutasjon i HAMP \\ Arvelig jernoverskudd; mutasjoner \\ i TfR2-genet på kromosom 7
}

\section{Ikke knyttet til hepcidin (sjeldne)}

Autosomalt dominant

Ferroportinsykdom; mutasjoner i ferroportin (SLC40A1)-genet på kromosom 2

Autosomalt recessivt

Aceruloplasminemi; mutasjon i ceruloplasmin-genet på kromosom 3

Medfødt atransferrinemi; mutasjon

i transferrin-genet på kromosom 3

hovedsakelig på syntesen av hepcidin (ramme 1). Felles for mutasjonene i HFE-, HJVog TfR2-genene, eller i genet for hepcidin (HAMP) selv, er at danningen av HFE-TfR2 komplekset og/eller signaloverføringen via HJV-BMP hindres, slik at hepcidinsyntesen ikke reguleres $\mathrm{i}$ forhold til plasma-jernets nivå.

Selv om DMT1 nedreguleres som respons på høyt jerninnhold i plasma og influks til enterocytten går ned, bremses ikke jernabsorpsjonen tilstrekkelig, fordi ferroportinnivået ikke går ned pga. manglende hepcidin. Jernabsorpsjon ved HFE-hemokromatose vises i figur 3c. Resultatet er at jernoverskudd i sirkulerende blod etterfølges av jernoverskudd i vevene fordi for mye jern passerer fra blod inn i parenkymale celler. I dette tilfellet er forholdet mellom sirkulerende jern og vevsjern høyt. Figur 6 viser jernmetabolisme ved HFEhemokromatose (15-17).

Det er to sjeldne arvelige tilstander (ramme 1) der jern akkumuleres i vev på grunn av redusert jerneksport: ferroportinsykdom, der den underliggende defekten er funksjonelt tap av den spesialiserte jerneksportøren ferroportin, og aceruloplasminemi, som skyldes tap av nødvendig ferroksidase (ceruloplasmin). Dermed hopes jern opp i makrofager og hepatocytter. Sammenliknet med jernmengden i vev kan mengden plasma-jern ved begge disse tilstandene være uforholdsmessig lav, og det kan gi en risiko for jernbegrenset erytropoese og anemi.

Ved atransferrinemi (ramme 1) kan jern absorbert i tarmen eller avgitt fra makrofagene ikke bli transportert til beinmargen pga. manglende transferrin. Anemien er konstant og alvorlig. Jernoverskudd i vev i denne situasjonen forekommer generelt fordi ufysiologisk høye nivåer av ikke-transferrinbundne former av jern tas opp i cellene.

\section{Sekundært jernoverskudd}

Noen årsaker til sekundært eller ervervet jernoverskudd er anemi som skyldes ineffektiv erytropoese, som ved talassemi, og f.eks. langvarig overforbruk av jerntilskudd.

Talassemi. Talassemi er en recessivt arvelig sykdom med redusert syntese av normale globinkjeder (18). Ved homozygot form får pasienten jernoverskudd både på grunn av hyppige blodtransfusjoner samt økt jernopptak fra tarmen som konsekvens av anemi og stimulert erytropoese.

Overforbruk av jerntilskudd. Selv om jernmetabolismen og jernabsorpsjonen normalt er nøye regulert, kan inntak av høye jerndoser, når jernbehovet på forhånd er dekket, føre til for stort jernopptak og deretter uønsket økning av jernlagrene. Det finnes eksempler på at kvinner, som f.eks. i forbindelse med svangerskap og fødsel har fått vite at de var «blodfattige» og derfor måtte ta jern, har fortsatt å bruke jerntabletter helt opp i 75-årsalder.

Vil høye jernlagre føre til patologiske forandringer, f.eks. i lever, hos individer med normal jernmetabolisme? Svaret er ja. I en studie av 120 pasienter med diagnosen hemokromatose var $9 \%$ negative for begge HFEmutasjonene, $\mathrm{C} 282 \mathrm{Y}$ og H63D. Flere av disse hadde hatt et langvarig (10-50 år) inntak av jernpreparater, og fire individer hadde serumferritinnivåer på 1 240-1 $880 \mu \mathrm{g} / 1$ kombinert med varierende grad av leverfibrose $(19,20)$. Kliniske forhold ved hemokromatose er beskrevet i dette nummer av Tidsskriftet (21).

\section{Konklusjon}

De senere årene har gitt oss interessant informasjon om hvordan reguleringen av jernbalansen foregår. Et viktig funn er hepcidins inaktivering og degradering av ferroportin og derved påvirkning av omfang og hastighet av jerneksport fra enterocytter og makrofager.

Leverproteinene HFE, transferrinreseptor 2 (TfR2), hemojuvelin (HJV) og beinmorfogeneseprotein (BMP) er nødvendige regulatorer for at hepcidin skal aktiveres som svar på jernmengden i plasma. Hepcidinproduksjonen nedreguleres ved jernmangel og oppreguleres ved jernoverskudd. Mangel på eller mutasjon $i$ ett av genene for disse proteinene eller i genet for hepcidin (HAMP) medfører at hepcidinsyntesen ikke reguleres i forhold til plasma-jernnivået.

Under normalfysiologiske forhold er reguleringen av jernbalansen god, men ved visse typer genfeil og ved inntak av store jernmengder svært dårlig.

Rutinemessig analyse av hepcidin vil sannsynligvis om få år være viktig ved diagnostikk av både jernmangelanemi og jernoverskudd.
Oppgitte interessekonflikter: Ingen

\section{Litteratur}

1. Latunde-Dada GO, Van der Westhuizen J, Vulpe CD et al. Molecular and functional roles of duodenal cytochrome B (Dcytb) in iron metabolism. Blood Cells Mol Dis 2002; 29: 356-60.

2. Zoller H, Theurl I, Koch RO et al. Duodenal cytochrome $b$ and hephaestin expression in patients with iron deficiency and hemochromatosis. Gastroenterol 2003; 125: 746-54.

3. Johnson DM, Yamaji S, Tennant J et al. Regulation of divalent metal transporter expression in human intestinal epithelial cells following exposure to non-haem iron. FEBS Lett 2005: 579: 123-9.

4. Latunde-Dada GO, Simpson RJ, McKie AT. Recent advances in mammalian haem transport. Trends Biochem Sci 2006; 31: 182-8.

5. Camachella C. Understanding iron homeostasis genetics through genetic analysis of hemochromatosis and related disorders. Blood 2005; 106 : 3710-7.

6. Ganz T. Hepcidin, a key regulator of iron metabolism and mediator of anemia of inflammation. Blood 2003; 102: 783-8.

7. Babitt JL, Huang FW, Wrighting DM et al. Bone morphogenetic protein signaling by hemojuvelin regulates hepcidin expression. Nat Genet 2006; 38 $531-9$.

8. Goswami T, Andrews NC. Hereditary hemochromatosis protein, HFE, interaction with transferrin receptor 2 suggests a molecular mechanism for mammalian iron sensing. J Biol Chem 2006; 281: 28494-8.

9. Andrews NC, Schmidt PJ. Iron homeostasis. Annu Rev Physiol 2007; 69: 69-85

10. Hentze MW, Kuhn LC. Molecular control of vertebrate iron metabolism: mRNA-based regulatory circuits operated by iron, nitric oxide, and oxidative stress. Proc Natl Acad Sci USA 1996, 93: 8175-82. 11. Hentze MW, Muckenthaler MU, Andrews NC. Balancing acts: molecular control of mammalian iron metabolism. Cell 2004; 117: 285-97.

12. Wood RJ, Ronnenberg AG. Iron. I: Shils ME, Olson $J A$, Shike $M$ et al, red. Modern nutrition in health and disease. 10. utg. Baltimore: Lippincott Williams \& Wilkins, 2005: 248-70.

13. Feder JN, Gnirke A, Thomas W et al. A novel MHC class I-like gene is mutated in patients with hereditaty haemochromatosis. Nat Genet 1996; 13: $399-408$.

14. Åsberg A, Hveem K, Thorstensen K et al. Screening for hemochromatosis: high prevalence and low morbidity in an unselected population of 65,238 persons. Scand J Gastroenterol 2001; 36: 1108-15.

15. Pietrangelo A. Hereditary hemochromatosis. Biochim Biophys Acta 2006; 1763: 700-10.

16. Pietrangelo A. Hemochromatosis: an endocrine liver disease. Hepatology 2007; 46: 1291-301.

17. De Domenico I, McVey Ward D, Nemeth E et al. Molecular and clinical correlates in iron overload associated with mutations in ferroportin. Haematologica 2006; 91: 1092-5.

18. Lilleholt K, Hallberg MH, Hagve T-A. Hemoglobinopatier og fremmedartede navn. Tidsskr Nor Lægeforen 2005; 125: 1164-7.

19. Bell H, Berg JP, Undlien DE et al. The clinical expression of hemochromatosis in Oslo, Norway. Excessive oral iron intake may lead to secondary hemochromatosis even in HFE C282Y mutation negative subjects. Scand J Gastroenterol 2000; 35 $1301-7$.

20. Borch-lohnsen B, Hauge A. Bør jernpreparater reseptbelegges? Tidsskr Nor Lægeforen 2001; 121: $460-2$.

21. Hagve T-A, Åsberg A, Ulvik R et al. Hemokromatose - fra underdiagnostisert kuriositet til folkesykdom. Tidsskr Nor Legeforen 2009; 129: 863-6.

Manuskriptet ble mottatt 17.7. 2008 og godkjent 23.2. 2009. Medisinsk redaktør Trine B. Haugen. 